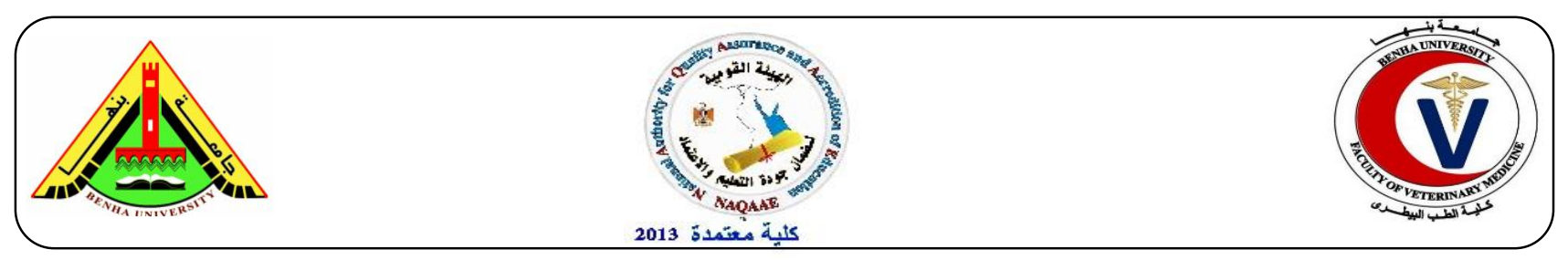

\title{
Assessment of some side effects of methotrexate
}

\author{
Abdel-Aziz S.A.; Said A. A.; Suhair A. Abd El-Latief and Nermin A. Helmy \\ Department of Pharmacology, Faculty of Veterinary Medicine, Zagazig University
}

\section{A B S T R A C T}

The present study was undertaken to study the immunotoxic effects of methotrexate (MTX) in male rats. This was done through estimating some interleukines IL-11 $\beta$, IL-6 and some immunological parameters as SOD, GSH, IgG, IgM, catalase, total Proteins and its fractions, some liver function parameters were also studied including serum AST, ALT, GGT activities and malondialdehyde. In this experimental study, thirty mature male albino rats weighing from 170-180 gm., aging 4-5 months age were used. Animals were classified randomly into 3 parallel groups as following: The $1^{\text {st }}$ group: rats were given distilled water $(1 \mathrm{ml})$ orally daily for 7 weeks and kept as control group, the $2^{\text {nd }}$ group: rats were given MTX $\left(0.1 \mathrm{mg} / 100 \mathrm{gm}\right.$. body weight weekly I.P. for 7 weeks and the $3^{\text {rd }}$ group: rats were given MTX (0.2 mg/100 gm. body weight weekly I.P. for 7 weeks. At the end of the study, 7 weeks post drug administration, all rats from each group were sacrificed and blood samples were collected into centrifuge tubes for separation of serum for determination of the above mentioned parameters. Methotrexate induced a significant increase in serum activities of AST, ALT, GGT, MDA, IL-6 and IL-1 $\beta$ and a significant decrease in serum activities of SOD, GSH and IgG and IgM as well as serum total protein, albumin and globulins when compared was normal control group. In all studies the effects were dose dependent. Thus patients treated with MTX should be supplemented with antioxidants, hepatoprotectives and immunostimulants to avoid its adverse effects.

Keywords: MTX rats, AST, ALT, GGT, MDA, IL-6, IL-1 $\beta$ SOD, GSH and IgG and IgM.

(http://www.bvmj.bu.edu.eg)

(BVMJ-35(2): 178-187, 2018)

\section{INTRODUCTION}

Methotrexate is a folate antagonist. It has beneficial antiproliferative, antimetabolic, and robust anti-inflammatory effects, which make it an efficacious treatment option in cancer and other disease processes that may benefit from these unique properties. Methotrexate it inhibits the enzyme dihydrofolate reductase (DHFR), an enzyme of the folate synthesis pathway that catalyzes the conversion of dihydrofolate to active tetrahydrofolate. Folate is essential for synthesis of thymidine required for DNA, RNA, and protein synthesis, (Kim, et al., 2009)

Methotrexate is a cytotoxic agent used to treat malignancies and a variety of non-malignant etiologies. Methotrexate was first used over 50 years ago for the treatment of psoriasis and is a mainstay in the treatment of malignancies, rheumatic, and inflammatory diseases such as psoriasis, psoriatic arthritis, inflammatory bowel disease (IBD), and rheumatoid arthritis, (Kalb et al., (2009). 
Methotrexate a well-known chemotherapeutic drug is also successfully employed in treating a number of non-neoplastic disease; such as Reiter's syndrome (Owen and Cohen 1979), polymyositis (Gianini and Collen, 1980), polyarteritis nodosa (Tannenbaum 1980), dermatomyositis Bohan et al., (1977), mycosis fungoides (Hanno et al., 1980), Wegener's granulomatosis (Capizzi and Bertino, 1971), cyclitis (Wong and Hersh, 1965), sarcoidosis (Lacher, 1968), rheumatoid arthritis (Bannwarth et al., 1994) and bronchial asthma (Mathur and Bhasiin, 1992).

The present study, was undertaken to further elucidate the possible adverse effects of this anti-rheumatoidal drug on DNA some immunotoxic effects on MDA, SOD, GSH, ALT \& AST, GGT, total protein, albumin, GGT, catalase enzyme, interleukiens IgG and IgM.

\section{Materials and methods}

2.1. (Methotrexate) ${ }^{\circledR}$ was obtained as vial of $50 \mathrm{mg}$. Pfizer, USA:

Dose: $0.1 \mathrm{mg} / 100 \mathrm{gm}$. b.wt. given i.p. once weekly, for 7 weeks (low dose) and $0.2 \mathrm{mg} / 100$ gm b.w. (high dose) (Tandon et al., 2015).

\subsection{Experimental:}

Thirty mature male albino rats weighing 170180 gm., aging 4-5 months old were used, they were obtained from laboratory animals unit, Faculty of Veterinary Medicine, Zagazig University.

The animals were classified randomly into 3 parallel groups as follows:

Group (1): Included 10 rats, received distilled water $(1 \mathrm{ml})$ orally daily for 7 weeks I.P and kept as control group.

Group (2): Included 10 rats, given therapeutic dose of MTX $0.1 \mathrm{mg} / 100 \mathrm{gm}$. body weight, I.P. weekly, for 7 weeks.

Group (3): Included 10 rats, given higher dose of MTX $0.2 \mathrm{mg} / 100 \mathrm{gm}$. body weight, I.P., weekly, for 7 weeks.

\subsection{Blood samples:}

At the end of the study 7 weeks post drug administration, all rats of each group were sacrificed and blood samples were collected into centrifuge tubes for separation of serum to be used for determination of the selected parameters.

After blood the collection, animals were dissected and their livers were wrapped in aluminum foil and kept at $-20{ }^{\circ} \mathrm{C}$ to be used for determination of GSH, SOD, MDA and CAT.

\subsection{Biochemical analysis:}

Serum ALT and AST were estimated spectrophotometrically according to Tietz, (1976), GGT, Glick, et al., (1986), serum total protein, was determined according to Henry, (1964), albumin, according to Doumas, et al., (1981) were assayed. Globulin, was calculated as the difference between serum total protein and serum albumin according to Kapale et al., (2008).

Determination of $\operatorname{lgM}$ and $\lg \mathrm{G}$ concentration, were measured using the single radial immunediffusion teclmique (SRID) according to Fahey and McKelvey (1965) and Mancini et al., (1965). Porcine $\operatorname{lgM}_{6}$ and $\operatorname{lgG}_{6}$ antisera were diluted in a barbital buffer solution ( $\mathrm{pH}$ 8.6).

Interleukins (IL-6 and IL- $\beta 1$ ): were quantitatively determined using kits of Mybiosource (Rat IL-6 PicoKine TM ELISA Kit Sandwich ELISA kit) in cell culture supernates, serum and plasma heparin, EDTA, citrate according to the method of Ferrari et al.(2003).

\subsection{Oxidative stress markers:}

Reduced Glutathione (GSH) was measured by determining the concentration of thiobarbituric acid reactive substances (Ohkawa et al., 1979) in fresh $10 \%$ liver homogenates. Concentrations of GSH and GSSG in liver were measured according to Hissin and Hilf (1976). Activities of catalase (Luck, 1963), superoxide dismutase (Crapo et al., 1978), glutathione peroxidase (Tappel, 1978), and glutathione reductase (Carlberg and 
Mannervik, 1975) were measured in $10 \%$ cytosols.

Determination of SOD activity in liver tissues. This assay relies on the ability of the enzyme to inhibit the phenazine methosulphatemediated reduction of nitroblue tetrazolium dye according to Nishikimi et al., (1972).

Malondialdehyde (MDA) was determined by using the method of (Satoh, 1978 and Ohkawa et al., 1979).

Catalase activity (CAT) was determined colorimetrically in liver homogenate according the method described by Aebi (1984).

2.6. Statistical Analysis:

Data were analyzed using computerized SPSS programs Version 21 (2011). The data were expressed as mean \pm S.E. The total variation was analyzed using one way ANOVA test (Snedecor and Cochran 1982).

\section{RESULTS}

Methotrexate induced a significant increase in serum activities of AST, ALT, GGT, MDA, IL-6 and IL-1 $\beta$ and a significant decrease in serum activities of SOD, GSH and $\mathrm{IgG}$ and $\operatorname{IgM}$ as well as serum total protein, albumin and globulins when compared was normal control group. In all studies the effects were dose dependent (Tables 1, 2 and 3).

Table 1: Effect of methotrexate (MTX) (0.1 \& $0.2 \mathrm{mg} / 100 \mathrm{gm}$. b.wt.) given I.P. once weekly for 7 weeks on serum enzyme activities of ALT, AST, GGT, total proteins, albumin and globulins of mature male rats. Mean \pm S.E. $n=10$.

\begin{tabular}{|c|c|c|c|c|c|c|}
\hline Parameter & $\begin{array}{l}\text { ALT } \\
\mathrm{u} / \mathrm{L}\end{array}$ & $\begin{array}{l}\mathrm{AST} \\
\mathrm{u} / \mathrm{L}\end{array}$ & $\begin{array}{l}\text { GGT } \\
\mathrm{u} / \mathrm{L}\end{array}$ & $\begin{array}{c}\text { Total } \\
\text { proteins } \\
\text { gm/dL }\end{array}$ & $\begin{array}{l}\text { Albumin } \\
\mathrm{gm} / \mathrm{dL}\end{array}$ & $\begin{array}{c}\text { Globulins } \\
\text { gm/dL }\end{array}$ \\
\hline \multirow{2}{*}{ Control } & 9.6 & 23.54 & 4.82 & 8.37 & 4.66 & 3.72 \\
\hline & $\pm 0.8^{\text {В }}$ & $\pm 2.54^{\mathrm{C}}$ & $\pm 0.34^{\mathrm{B}}$ & $\pm 0.27^{\mathrm{A}}$ & $\pm 0.19^{\mathrm{A}}$ & $\pm 0.33^{\mathrm{A}}$ \\
\hline \multirow{2}{*}{ MTX (Low dose) } & 19.6 & 39.69 & 12.67 & 7.04 & 3.89 & 3.82 \\
\hline & $\pm 3.2^{\mathrm{C}}$ & $\pm 3.13^{\text {B }}$ & $\pm 1.39^{\mathrm{A}}$ & $\pm 0.25^{\text {B }}$ & $\pm 0.07^{\mathrm{B}}$ & $\pm 0.4^{\mathrm{A}}$ \\
\hline \multirow{2}{*}{ MTX (High dose) } & 36.6 & 55.97 & 14.2 & 6.67 & 3.68 & 2.9 \\
\hline & $\pm 2.70^{\mathrm{A}}$ & $\pm 4.4^{\mathrm{A}}$ & $\pm 1.12^{\mathrm{A}}$ & $\pm 0.32^{\mathrm{B}}$ & $\pm 0.28^{\mathrm{B}}$ & $\pm 0.28^{\mathrm{AB}}$ \\
\hline
\end{tabular}

Means with different superscripts in the same column are significantly different at $\mathrm{P}<0.05$ 
Table 2: Effect of methotrexate (MTX) $(0.1 \& 0.2 \mathrm{mg} / 100 \mathrm{gm}$. b.wt.) given I.P. once weekly for 7 weeks on serum IgM \& IGG; CAT, SOD, GSH \& MDA in liver homogenate of mature male rats. Mean \pm S.E. $n=10$.

\begin{tabular}{|c|c|c|c|c|c|c|}
\hline Parameter & $\begin{array}{c}\operatorname{IgM} \\
\mathrm{mg} / \mathrm{dL}\end{array}$ & $\begin{array}{c}\text { IGG } \\
\mathrm{mg} / \mathrm{dL}\end{array}$ & $\begin{array}{c}\text { Catalase } \\
\text { IU/L }\end{array}$ & $\begin{array}{l}\text { SOD } \\
\text { IU/ml }\end{array}$ & $\begin{array}{c}\text { GSH } \\
\mathrm{mmol} / \mathrm{L}\end{array}$ & $\begin{array}{c}\text { MDA } \\
\mathrm{mmol} / \mathrm{ml}\end{array}$ \\
\hline \multirow{2}{*}{ Control } & 117.8 & 1012.8 & 930.75 & 6.94 & 0.93 & 9.32 \\
\hline & $\pm 2.63^{\mathrm{A}}$ & $\pm 22.7^{\mathrm{A}}$ & $\pm 19.84^{\mathrm{A}}$ & $\pm 0.03^{\mathrm{A}}$ & $\pm 0.07^{\mathrm{A}}$ & $\pm 0.48^{\text {В }}$ \\
\hline \multirow{2}{*}{ MTX (Low dose) } & 46.33 & 690 & 401.9 & 1.1 & 0.43 & 10.06 \\
\hline & $\pm 1.20^{\mathrm{C}}$ & $\pm 6.80^{\mathrm{C}}$ & $\pm 22.2^{\mathrm{B}}$ & $\pm 0.08^{\mathrm{C}}$ & $\pm 0.01^{\mathrm{C}}$ & $\pm 1.10^{\mathrm{B}}$ \\
\hline \multirow{2}{*}{ MTX (High dose) } & 97.4 & 900.2 & 235.0 & 1.50 & 0.6 & 18.44 \\
\hline & $\pm 5.31^{\text {В }}$ & $\pm 16.8^{\text {В }}$ & $\pm 19.66^{\mathrm{C}}$ & $\pm 0.10^{\text {В }}$ & $\pm 0.008^{\mathrm{B}}$ & $\pm 1.66^{\mathrm{A}}$ \\
\hline
\end{tabular}

Means with different superscripts in the same column are significantly different at $\mathrm{P}<0.05$

Table 3: Effect of Methotrexate (MTX) (0.1 \& $0.2 \mathrm{mg} / 100 \mathrm{gm}$. b.wt.) given I.P. weekly for 7 weeks on IL1 $\beta$ and IL 6 of mature male rats. Mean \pm S.E. $n=10$.

\begin{tabular}{lcc}
\hline Parameter & IL-1 & IL-6 \\
& pg/ml & pg/ml \\
\hline Control & $0.27 \pm 0.02^{\mathrm{A}}$ & $0.271 \pm 0.02^{\mathrm{A}}$ \\
MTX (Low dose) & $0.17 \pm 0.03^{\mathrm{B}}$ & $0.147 \pm 0.02^{\mathrm{B}}$ \\
MTX (High dose) & $0.21 \pm 0.02^{\mathrm{A}}$ & $0.254 \pm 0.05^{\mathrm{A}}$ \\
\hline
\end{tabular}

Means with different superscripts in the same column are significantly different at $\mathrm{P}<0.05$ may also depend on its action on other related

\section{DISCUSSION}

Methotrexate is a widely used drug in the treatment of patients with malignant disease (Stark et al., 1989). It has become the disease modifying drug of choice for the treatment of rheumatoid arthritis (Godfrey et al., 1998 and Neidel et al., 1998). Methotrexate is also an effective but potentially toxic treatment for psoriasis (Pearce and Wilson, 1996). Recent data indicate that the anti-inflammatory effect of methotrexate is mediated by adenosine. However, methotrexate side-effects can only partly be explained by folate antagonism and metabolic pathways. (Van Ede et al., 1998).

The obtained results revealed that methotrexate when given intraperitoneally once weekly for successive 7 weeks in its two dose levels ( $0.1 \& 0.2 \mathrm{mg} / 100 \mathrm{gm}$. b.wt.) afforded a significant increase in the activities of ALT, AST and GGT compared with those of control group, the effect was dosedependent (Table 1). These results could be possibly attributed to liver damage evidenced in another study carried out in our lab (AbdelAziz et al., 2018). These changes includes: Congestion of the central vein with individual 
coagulative necrosis of hepatocyte, severe hydropic degeneration of the hepatocytes, portal congestion with intensive portal infiltration with leukocytes mostly mononuclear cells, focal area of coagulative necrosis completely replaced by mononuclear cells mainly lymphocytes, portal fibrosis, congestion, and hyperplasia of the lining epithelium of the bile ducts, severe vacuolar and hydropic degeneration of most hepatocytes with numerous pyknotic nuclei besides vascular congestion, focal aggregation of mononuclear cells with hyperplasia of Von Kupffer cells and marked leukocytic infiltration of the portal area with hyperplastic bile ductules.

The obtained results were also supported by the initial reports of Colsky (1955) on leukaemic patients treated with MTX which showed hepatotoxicity. Coe \& Bull, (1969) and Epstein \& Craft, (1969) reported liver cirrhosis in patient suffering from psoriasis and treated with methotrexate. Later Weinstein and Frost (1973) as well as a single long -term studies by Reese et al., (1974); Robinson et al., (1980) and Zachariae \& Sogaard, (1987). Confirmed that the drug may induce liver damage, which in some psoriatic patients will lead to fibrosis or cirrhosis. Authors attributed these degenerative changes to folate depletion. The changes in the livers of folate -deficient rats seem very similar to the MTX-induced liver changes of liver morphology of humans.

Hepatic cells contain a group of enzymes which have been used as markers for monitoring liver damage induced by chemicals, these enzymes are ALT, AST and ALP which are elevated in blood following liver cell damage (Hukkeri et al., 2002). Serum ALT is present mainly in liver and kidney and other tissue, like heart and skeletal muscle in fewer concentrations. These enzymes are very sensitive to necrotic or inflammatory liver injury and consequently increased in serum indicating liver disease (Deska and Pagana, 1998).

Hepatocytes contain substantial amount of ALT in their cytosol and a major increase in serum ALT indicate hepatocellular leakage of the enzyme but do not always means a primary or irreversible hepatic disease (Rej, 1984).

The degree of liver damage causing increased ALT activity can range from mild and irreversible injury (Sublethal cell injury) sufficient to cause leakage of cellular enzymes through the membrane but having no appreciable effect on cellular functions, to cell necrosis with a total loss of function as caused by infectious hepatitis. The increase in the enzyme activity is proportional to the amount of cells injured and not to the degree of injury (Talwar and Srivastava, 2003).

AST is found primarily in heart, liver, skeletal muscle, kidney and pancreas, so it is not as specific for liver disease as ALT (Burtis and Edward, 1999).

Although ALT is present in the cytosol, AST is present in the mitochondria. Increased serum ALT reflects cell membrane damage and leakage while AST increase reflect more serious liver damage because the mitochondria are not damaged as readily as cell membrane. AST is present in significant quantities in many other tissues including muscle and RBCs.

GGT is an enzyme that is primarily present in the liver, kidney and pancreas. The highest enzyme level is present in the renal tissue. The enzyme present in the serum appears to originate primarily from the hepatobiliary systems and GGT activity is elevated in any and all forms of liver disease. It is more sensitive than ALP, leucine aminopeptidase, AST and ALT in detecting obstructive jaundice, cholangitis and cholecystitis, its rise 
occurs earlier than other enzymes and persist longer (Burtis and Edward, 1999).

The elevated serum ALT, AST and GGT in conjunction with the histopathological finding previously reported in the current study emphatically point to hepatic cell damage.

Other experimental approach using the same protocol revealed a significant decrease in the activities of catalase, SOD, GSH in liver tissue with a significant increment in MDA concentration.

One really compelling argument for our finding is the possibility that a common thread is running through all of our results. It is quite plausible, therefore that an entangled passage way, oxidative stress would fit the case. Certainly, this stress would call for the suppressed oxidative enzymes and testify to hepatic and renal alteration (Harada, 1984). These findings fit with that reported in our study.

Oxidative stress can be defined as the challenge presented by reactive oxygen species to different cellular components due to the imbalance between oxidant and antioxidant capacities (Haliwell and Gutteridge, 1998).

The presence of oxidative stress can be investigated either by detection of oxygen free radicals or other similar substances, generally called reactive oxygen species (ROS) or by detection of antioxidants and damaged products of essential biomolecules (e.g. lipid peroxidation products as MDA) as a consequence of ROS activity. Increased generation of ROS in vivo can lead to the depletion of one more antioxidants (e. g. ascorbate or glutathione) which can be measured as an index of oxidative stress (Haliwell and Gutteridge, 1998).

Free radicals play an important role in drug induced damage to the liver, kidney and other organs (Cantin and Woods, 1993 and MingeotLeclerq and Tulkens, 1999).

Concerning the effect on MDA, the obtained results revealed a significant increase in MDA level indicating lipid peroxidation which might be possibly attributed to generation of free radicals.

The obtained results were compatible with Daggullil, et al., (2014), who found that MTX increase the total oxidant status (TOS) and oxidative stress index (OSI) and reduced total antioxidant activity.

The decreased serum total protein obtained in this study represented by decreased serum albumin and globulin could be possibly attributed to inhibition of RNA synthesis (Kim et al., 2009), they found that MTX inhibits the enzyme dihydrofolate reductase (DHFR), an enzyme of the folate synthesis pathway that catalyzes the conversion of dihydrofolate to active tetrahydrofolate. Folate is essential for synthesis of thymidine required for DNA, RNA, and protein synthesis. Our results coincide also with Kaneko (1980). They stated that the liver is the sole site of albumin synthesis and hypoalbuminemia is an important feature of liver diseases.

Methotrexate induced a significant reduction in both $\operatorname{IgM} \& \operatorname{IgG}$ and $1 \mathrm{~L}-\mathrm{I} \beta$ coupled with a significant decrease in CAT \& SOD and GSH. Undoubtedly, the first result pinpoints to a significant inhibition of the humoral arm of the immunity. On another level it could be urged that a cross talk could be hinted at the oxidative stress and the immunosuppressive effect.

Taken together, the previous findings hint at a substantial interplay between oxidative stress and the immune system. In fact, the previous literature point to the same way. The immune system is limited by oxidative stress and dietary selenium promotes optimal antioxidative status and greatest immune defense 
in greatest immune defense in pacu piaractus mesopotamicus, (Biller-Takahishi et al., 2005). In line with this concept, antioxidant and physical exercise have favorable effect on the immune system in the oxidative stress condition in aging and hypertension (Dela Fuente et al., 2005). In addition, oxidative stress has negative impact on T-cell functions (Bennett and Griffith, 2013).

\section{Conclusion}

It could be concluded that, methotrexate afforded deleterious effects on all the examined hepatic function parameters, oxidant/ anti-oxidants status as well as the tested indicators of the immune function. In addition patients treated with MTX should be supplemented with antioxidants, hepatoprotectives and immunostimulants to avoid its adverse effects.

\section{REFERENCES}

Abdel-Aziz S.A.; Said A.A.; Suhair A. AbdelLatief and Nermin A. Helmy (2018): Assessment of some side effects of methotrexate. MVSc. Pharmacology presented to Faculty of Veterinary Medicine, Zagazig University.

Aebi, H. (1984): Catalase in vitro methods enzymol., 105:121-126.

Bannwarth B., Labat L., Moride Y. and Schaeverbeke T. (1994): Methotrexate in rheumatoid arthritis. An. update Drugs, 47, 25-30.

Bennett, S.T. and Helen R. Griffith (2013): The regulation of $\mathrm{T}$-cell function by oxidative stress. Studies on Arthritis and Joint Disease. p 33-48.

Biller-Takahishi I.D.; Takahishi I.S. Mingatto F.E and Urbinati E.C. (2005): Fish; Shell Fish Immunol., 47(1):360-367.
Bohan A., Peter J.B., Ejowman R.L. and Pearson C.M. (I977): A computer assisted analysis of 153 paticnts with polymyositis and de1matom: yositis. Medicine, 56, 255-286.

Burtis, C.A. and Edward, R.A. (1999): Tietz Textbook of Clinical Chemistry. Philadelphia: W.B. Saunders.

Cantin, A. and Woods, D.E.(1993): Protection by antibiotics against Myeloperoxidase-dependant cytotoxicity to lung epithelial cells in vitro, J. Clin Invest. 91: 38-45.

Capizzi R.L. and Bertino J.R. (1971): Methotrexate therapy of Wegener's granulomatosis. Ann. Int. Med., 74, 7479.

Carlberg, I. and Mannervik B. (1975). Purification and characterization of the flavoenzyme glutathione reductase from rat liver. J. Biol. Chem., 250, 5475-5480.

Coe, R. \& Bull, F. (1969): Cirrhosis associated with methotrexate treatment of psoriasis. Journal of the American Medical Association 206, 1515-1520.

Colsky, J., Greenspan, E. and Warren, T. (1955): Hepatic fi brosis in children with acute leukemia after therapy with folic acid antagonists. Archives of Pathology 59, 198.

Crapo, J.D.; McCord J.M. and Fridovich I. (1978). Preparation and assay of superoxide dismutase. Meth. Enzymol., 53, 382-393.

Daggulli1, M.; Dede1, O.; Utangac1, M.; Bodakci, M.N.; Hatipoglu, N. K.; Penbegul, N.; Sancaktutar, A. A.; Bozkurt, Y.; Türkçü, G. and Yüksel H. (2014): Protective effects of carvacrol 
against methotrexate-induced testicular toxicity in rats. Int J Clin Exp Med; 7(12):5511-5516.

Dela Fuente, M.; Heman, Z.A. and Vallego, M.C. (2005): Antioxidant Redox Signal September-October, 7 (9-10), 1356.

Deska, P.K. and Pagana,T.J.(1998): Mosby's Manual of Diagnostic and Laboratory Tests. Philadelphia: Mosby, Inc.

Doumas, B.T., Young, D.S., Burtis, A., Tietz, N. and Biggs, H.G. (1981): Colorimetric determination of albumin. Clin. Chem. Vol. 7: Edited by Cooper, G.R. New York, Academic press, 495496.

Epstein, E. and Croft, J. (1969): Cirrhosis following methotrexate administration for psoriasis. Archives of Dermatology 100, 531-534.

Fahey, L.J. and McKelvey E.M. (1965): Quantitative determination of serum immunoglobulins in antibody agar plates. J. Immunol. 94, 84.

Ferrari, S.L., Ahn-Luong, L., Garnero, P., Humphries, S.E., Greenspan, S.L. (2003): Two promoter polymorph isms regulating interleukin-6 gene expression are associated with circulating levels of C-reactive protein and markers of bone resorption in postmenopausal women. J. Clin. Endocr. Metab. 88 255-259,

Gianini M. and Collen J.P. (1980): Treatment of dermatomyositis with methotrexate and prednisone. Arch. Dermatol., 115, $1251-1252$.

Glick M.R.; Ryder K.W. and Jackson S.A. (1986): Graphical Comparisons of Interferences in Clinical Chemistry
Instrumentation, Clin. Chem., 32,470474.

Godfrey, C.; Sweeney, K.; Miller,K.; Hamilton, R. and Kremer,J. (1998): "The population pharmacokinetics of long-term methotrexate in rheumatoid arthritis". B.\}. Clin. Pharmacal., 46: $369-76$.

Haliwell, B. and Gutteridge, J.M.C. (1998): Free Radicals in Biology and Medicine. Haliwell B Gutteridge JMC Eds. 351429.

Hanno R., Gruber G.G., Owen L.G. and Callen J.P. (1980): Methotrexate in psoriasis: a brief review of indications, usage and complication of methotrexate therapy. J. Am. Acad. Dermat., 2, 171-174.

Harada, T. (1984): CG117 (CGA 48988)-24 month oral chronic toxicity study in dogs. Report dated 6 October 1984, from Institute of Environmental Toxicology, Japan, Submitted to WHO by Syngenta Crop protection AG, Basle Switzerland.

Henry, R.J. (1964): Clinical Chemistry, Harper \& Row Publishers. New York. P: 181.

Hissin, P.J. and Hilf, R. (1976): A Fluorometric method for determination of oxidized and reduced glutathione in tissues. Analyt. Biochem., 74, 214-226.

Hukkeri, V.I., Jaiprakash, B., Lavhale, M.S., Karadi, R.V. and Kuppast, I.J.(2002): Hepatoprotective activity of Anthus excelsa Roxb. Leaf extracts on experimental liver damage in rats. J.Pharmacogn.; 11: 120-128.

Kalb R.E., Strober B., Weinstein G. and Lebwohl M. (2009): Methotrexate and psoriasis: 2009 National Psoriasis 
Foundation Consensus Conference. J. Am. Acad. Dermat., 60:824-37.

Kaneko, J.J. (1980): Clinical Biochemistry of Domestic Animals. $3^{\text {rd }}$ Ed., Academic Press. Inc.

Kapale P.M.; Jagtap D.G.; Badukale D.M. and Sahatpure S.K. (2008): Serum total proteins and serum total cholesterol levels in Gaolao. Vet. World, 1 (4), 115116.

Kim Y.J., Song M. and Ryu J.C. (2009): Mechanisms underlying methotrexateinduced pulmonary toxicity. Expert Opinion on Drug Safety, 8:451-8.

Lacher M.J. (1968): Spontaneous remission or response to methotrexate in sarcoidosis. Ann. Int. Med. 69, 1247-1245.

Luck, H. (1963): Catalase. In methods of enzymatic analysis (H.U. Bergmeyer, Ed.), pp. 885-888. Academic Press, New York.

Mancini, G.A.; Carbonara O. and Heremans J. F. (1965). Immunochemical quantization of antigens by single radial immunodiffusion, immunochemistry, 2 , 235.

Mathur R. and Bhasiin K.C. (1992): Methotrexate as; I steroid sparing drug in bronchial asthma. Lung India, 10, 5760 .

Mingeot-Leclercq, M.P. and Tulkens, P.M. (1999): Aminoglycosides: nephrotoxicity. Antimicrob Agents chemother. 43: 1003-1012.

Neidel, J.; Sova, L.; Schroers, B.; Sintermann, F.; Manzke, O. and Bohlen, H. (1998): "Effects of methotrexate on normal articular cartilage in vitro and in vivo". Ann. Rheum. Dis., 57:414-21.
Nishikimi, M.; Roa, N.A. and Yogi, K (1972): The occurrence of superoxide anion in the reaction of reduced phenazine methosulfate and molecular oxygen. Biochem. Bioph. Res. Common., 46, 849-854.

Ohkawa, H., Ohishi, W. and Yagi, K., (1979): Assay for lipid peroxides in animal tissues by thiobarbituric acid reaction. Anal. Biochem.; 95(2),:351-358.

Owen E.T. and Cohen M.L. (1979): Methotrexate in Reiter's disease. Ann. Rheum. Dis., 38, 48-50.

Pearce, H. P. and Wilson, B. B. (1996): "Erosion of psoriatic plaques an early sign of methotrexate toxicity". J. Am. Acad. Dermatol., 35(2): 835-8.

Reese, L., Grisham, J., Aach, R. and Eisen, A. (1974): Effects of methotrexate on the liver inpsoriasis. Journal of Investigative Dermatology 62, 597602.

Rej, R. (1984): Measurement of aminotransferases: Part 1. Aspartate aminotransferase. CRC Crit Rev Clin Lab Sci. 21:99-106.

Robinson, J., Baughman, R., Auerbach, R. and Cimis, R. (1980): Methotrexate hepatotoxicity in psoriasis. Archives of Dermatology 110, 413-415.

Satoh K., (1978): Serum lipid peroxide in cerebro vascular disorders: determined by a new colorimetric method. Clinica Chimica Acta.; 90, 37-43.

Snedecor, W. and Cochran, G. (1982): Statistical Methods IOWA University Press $7^{\text {th }}$ Ed. Ames, IOWA USA.

Stark, A.N.; Jackson, G.; Carey, P.J.; Arfeen, S. and Proctor, S.J. (1989): "Severe renal toxicity due to intermediatedose 
methotrexate". Cancer Chemother. Pharmacol., 24: 243-5.

Talwar, G.P. and Srivastava, L.M.(2003): Textbook of Biochemistry and human biology, 3rd ed. Prentice-Hall ofIndia, Pvt. Ltd., New Delhi, India.

Tandon, R.; Rahman, N.; Moinuddin, A.; Gaur, M.; Battan, G. and Faruqui, N.A. (2015): Histomorphometric study on the effects of methotrexate on gonads: An experimental study in albino rat. Acad. Anatom. Int., 1(1):43-46.

Tannenbaum H., (1980): Combined therapy with methotrexate and prednisone in polyarteritis nodosa. Cand. Med. Assoc. J. 123, 893-894.

Tappel, A.L. (1978). Glutathione peroxidase and hydroperoxides. Meth. Enzymol., 52, 506-513.

Tietz, N.W. (1976): Fundamentals of Clinical Chemistry. W.B. Saunders Co. Philadelphia.

Van-Ede, A.E.; Laan, R.F.; Blom, H.J.; DeAbreu, R.A. and Van de Putte, L. B. (1998): "Methotrexate in rheumatoid arthritis: an update with focus on mechanisms involved in toxicity". Semin. Arthritis Rheum., 27: 277-92.

Weinstein, G. and Frost, P. (1973): Methotrexate for psoriasis: a new therapeutic schedule. Archives of Dermatology 103, 33-38.

Witty L.A., Steiner F., Curfman M, Webb D. and Wheat L.J. (1992): Disseminated histoplasmosis in patients receiving low dose methotrexate therapy for psoriasis. Arch. Dermat., 128, 91-93.

Wong G.V. and Hersh E.M. (1965): Methotrexate in the therapy of cyclitis.
Trans. Am. Acad. Ophthal. Otolaryn. 1, 279-293.

Zachariae, H. and Søgaard, H. (1987): Methotrexate-induced liver cirrhosis. A follow-up. Dermatologica 75, 178-182. 